\title{
Pembuatan seal tabung gas karet alam dengan filler pasir kuarsa sebagai pengganti karbon hitam
}

\section{The making of natural rubber-based gas cylinder seals with quartz sand as the filler to replace carbon black}

\author{
Suharman ${ }^{1, *}$, M. Harun ${ }^{2}$ \\ 'Pusat Penelitian dan Pengembangan Teknologi Industri dan Kekayaan Intelektual, \\ J1. Jend. Gatot Subroto Kav. 52-53 Jakarta 12950, Indonesia \\ ${ }^{2}$ Balai Riset dan Standardisasi Industri Palembang, Jl. Perindustrian II No.12 Km 9 Palembang 30961, Indonesia \\ * Penulis korespondensi. Telp. +6221 5256112, Fax. +6221 5256116 \\ E-mail: suharman.hadi@gmail.com
}

Diterima: 10 Januari 2017 Direvisi: 09 Mei 2017 Disetujui: 10 Mei 2017

\begin{abstract}
This research aimed to make natural rubber-based gas cylinder seals with quartz sand as the filler to replace carbon black. The experiments consisted of the use of $10 \mathrm{phr}, 20 \mathrm{phr}, 30 \mathrm{phr}, 40 \mathrm{phr}$, and $50 \mathrm{phr}$ of quartz sand. The gas cylinder seals produced underwent a test according to the Indonesian National Standard (SNI) 7655:2010. The test generated the following results: the value of hardness ranged from $51 \pm 6$ to $60 \pm 5$ Shore A, the value of tensile strength ranged from 67 to $72 \mathrm{~kg} / \mathrm{cm}^{2}$, the value of elongation at break ranged from 414 to $457 \%$, the value of the compression set ranged from 25 to 61\%, after aging, and ozone resistance with no cracks. Natural rubber-based gas cylinder seals with quartz sand as the filler to replace carbon black met the requirements specified by SNI 7655:2010 in terms of the criteria of hardness, elongation at break, after aging and ozone resistance.
\end{abstract}

Keywords: quartz sand, carbon black, gas cylinder seal.

\section{ABSTRAK}

Tujuan penelitian adalah membuat seal tabung gas berbahan karet alam dengan bahan pengisi (filler) pasir kuarsa sebagai pengganti karbon hitam. Percobaan terdiri atas penggunaan $10 \mathrm{phr}, 20 \mathrm{phr}, 30 \mathrm{phr}, 40 \mathrm{phr}$ dan $50 \mathrm{phr}$ pasir kuarsa. Seal tabung gas yang dihasilkan diuji menurut Standar Nasional Indonesia (SNI) 7655:2010. Hasil penggujian diperoleh nilai kekerasan (hardness) antara $51 \pm 6$ sampai $60 \pm 5$ Shore A, tegangan putus (tensile strength) antara 67 sampai $72 \mathrm{~kg} / \mathrm{cm}^{2}$, perpanjangan putus (elongation at break) 414-457\%, pampatan tetap (compression set) $25-61 \%$, pengusangan (after aging) dan ketahanan ozon yang tidak ada keretakan. Seal tabung gas berbahan karet alam yang dibuat dengan bahan pengisi pasir kuarsa sebagai pengganti karbon hitam dapat memenuhi persyaratan SNI 7655:2010 untuk kriteria hardness, elongation at break, after aging dan ketahanan ozon.

Kata kunci: pasir kuarsa, karbon hitam, seal tabung gas.

\section{PENDAHULUAN}

Seal tabung gas adalah karet seal yang digunakan pada tabung gas sebagai konektor antara gas LPG dan kompor. Seal tabung gas merupakan bagian yang sangat penting yang berdampak pada resiko tinggi. Kualitas seal tabung gas yang tidak baik dapat menyebabkan terjadi kecelakaan seperti tabung gas meledak, kebocoran, kebakaran dan sebagainya. Oleh karena itu pembuatan seal tabung gas harus memenuhi standar SNI.

Seal tabung gas harus terbuat dari karet yang elastis dan memiliki daya rekat yang kuat. Kriteria ini ada pada jenis karet alam. SNI yang mengatur tentang spesifikasi dan persyaratan seal tabung gas adalah SNI 7655:2010 tentang karet perapat (rubber seal) pada katup liquid petroleum gas (LPG).

Pembuatan seal tabung gas dilakukan dengan beberapa tahap yaitu pencampuran karet dengan bahan tambahan (compounding), pencetakan (moulding) dan pemasakan atau vulkanisasi. Sifat fisika seal tabung gas sangat dipengaruhi oleh penggunaan jenis karet dan bahan tambahan. 
Bahan tambahan meliputi, bahan pengisi, bahan penggiat, bahan percepat, bahan pelunak, bahan pencegah ozon, dan lain-lain. Salah satu faktor penentu kualitas produk barang jadi karet seperti seal tabung gas adalah penggunaan bahan pengisi atau filler.

Bahan pengisi yang umum dipakai adalah karbon hitam. Pasir kuarsa merupakan bahan alam yang mengandung silika dioksida $\left(\mathrm{SiO}_{2}\right)$. Kandungan silika dioksida pada pasir kuarsa memungkinkan untuk menjadi bahan pengisi pengganti karbon hitam. Oleh karena itu perlu dilakukan penelitian terhadap kemungkinan penggunaan pasir kuarsa sebagai bahan pengisi pengganti karbon hitam.

Penggunaan pasir kuarsa sebagai bahan pengisi merupakan upaya pemanfaatan sumber daya alam lokal mengingat karbon hitam semakin sulit didapat dan harganya mahal. Di Sumatera Selatan, pasir kuarsa banyak terdapat di kecamatan Tulung Selapan dan kecamatan Cengal Kabupaten Ogan Komring Ilir. Pasir kuarsa merupakan bahan galian yang mengandung $\left(\mathrm{SiO}_{2}\right)$ sebesar $97-98 \%$. Pasir kuarsa di alam berukuran halus sampai agak kasar (200 mesh sampai $2 \mathrm{~mm}$ ) berwarna putih keabu-abuan, berasal dari batuan induk yang mengalami pelapukan dan mengalami sedimentasi (Sodik, 1995).

Penelitian mengenai bahan pengisi pada pembuatan barang jadi karet telah banyak dilakukan. Fachry et al. (2012) dalam penelitiannya membuktikan bahwa kaolin dapat dijadikan sebagai bahan pengisi pada pembuatan souvenir dari karet dan telah terbukti dapat memperbaiki elastisitas dan kekerasan produk yang dihasilkan. Lebih lanjut Prasetya (2012) juga telah membuktikan bahwa arang aktif dari serbuk gergaji dapat digunakan sebagai filler pada pembuatan kompon ban kendaraan roda dua. Sama halnya dengan kaolin dan arang aktif dari serbuk gergaji, cangkang telur ayam yang mengandung kalsium karbonat, magnesium karbonat, dan kalsium fosfat juga telah digunakan sebagai bahan pengisi pada pembuatan barang jadi karet (Nella et al., 2016).

Filler pada pembuatan barang karet dapat mempengaruhi sifat mekaniknya. Sasongko (2012) menemukan bahwa lama waktu vulkanisasi dipengaruhi oleh luas permukaan bahan dan ukuran partikel dari filler yang dipergunakan. Bentuk partikel tidak berpengaruh terhadap cure time dan scorch time melainkan berpengaruh terhadap sifat mekanis kompon atau barang karet.
Selain sifat mekanik, filler juga akan mempengaruhi sifat fisik dari produk yang dihasilkan (Cifriadi \& Maspanger, 2005). Berbagai bahan yang dapat dijadikan sebagai filler pada pembuatan barang jadi karet diantaranya abu sekam padi dan arang aktif tempurung kelapa (Prasetya \& Marlina, 2013; Marlina et al., 2015; Nasution, 2006), nano brushing rubber (Bondan, 2013), abu terbang atau abu briket batubara dan arang cangkang sawit (Cifriadi \& Maspanger, 2005; Nuyah, 2012; Vachlepi \& Suwardin, 2015), kaolin (Daud, 2015), komposit batu apung dan clay (Bahri, 2015), campuran silika dan kulit kerang darat (Marlina \& Rahmaniar, 2012; Fachry et al., 2014).

Penelitian ini dilakukan untuk mendapatkan formula penggunaan pasir kuarsa sebagai bahan pengisi pengganti karbon hitam pada pembuatan seal tabung gas (rubber seal).

\section{BAHAN DAN METODE Bahan Penelitian}

Bahan yang digunakan terdiri atas karet alam (SIR 10), pasir kuarsa, karbon hitam, paraffinic oil, $\mathrm{ZnO}$, asam stearat, CBS, dan sulfur. Pasir kuarsa yang digunakan adalah pasir kuarsa yang dihaluskan 400 mesh diperoleh dari Kabupaten Ogan Komering Ilir Sumatera Selatan.

\section{Peralatan Penelitian}

Peralatan terdiri atas mesin giling dua roll (open mill), cetakan (moulding), alat pres, neraca analitis, alat uji kekerasan, alat uji kuat tarik, alat uji compression set, oven, dan alat uji ketahanan ozon.

\section{Metode Penelitian}

Percobaan dilakukan dengan lima formula dan tiga ulangan. Pengujian sifat fisika sesuai SNI 7655:2010. Formula pembuatan seal tabung gas seperti pada Tabel 1.

\section{Pembuatan kompon}

Pembuatan kompon diawali dengan proses mastikasi yaitu penggilingan karet sampai matang yang ditunjukkan dengan berwarna kuning coklat (pada suhu $60-70^{\circ} \mathrm{C}$ ). Saat penggilingan karet disayat pada bagian pinggir kiri dan kanan sambil terus digiling. Penambahan bahan penggiat (paraffinic oil dan CBS) secara merata pada permukaan karet yang digiling. Penambahan zat anti oksidan $(\mathrm{ZnO})$, penambahan bahan pengisi (pasir kuarsa dan karbon hitam) 2/3 bagian dari formula, dan bahan pelunak (asam stearat) sambil terus digiling 
Tabel 1. Formula pembuatan seal tabung gas.

\begin{tabular}{lccccc}
\hline \multirow{2}{*}{ Bahan } & \multicolumn{5}{c}{ Formula kompon (phr) } \\
\cline { 2 - 6 } & (A) & (B) & (C) & (D) & (E) \\
\hline SIR 10 & 100 & 100 & 100 & 100 & 100 \\
ZnO & 5 & 5 & 5 & 5 & 5 \\
Asam stearat & 2 & 2 & 2 & 2 & 2 \\
Pasir kuarsa & 10 & 20 & 30 & 40 & 50 \\
Karbon hitam & 50 & 40 & 30 & 20 & 10 \\
Paraffinic oil & 10 & 10 & 10 & 10 & 10 \\
CBS & 1 & 1 & 1 & 1 & 1 \\
Sulfur & 2 & 2 & 2 & 2 & 2 \\
Jumlah (phr) & 180 & 180 & 180 & 180 & 180 \\
\hline
\end{tabular}

(karet dipotong kiri dan kanan sambil terus digiling agar tercampur secara merata). Penambahan sisa bahan pengisi dan bahan pelunak. Penambahan bahan pencepat dan terakhir penambahan bahan pemvulkanisasi (sulfur). Pembuatan kompon selesai dan kompon siap untuk dicetak.

\section{Pencetakan seal tabung gas}

Sebelum digunakan cetakan dibersihkan terlebih dahulu dan diolesi dengan minyak silikon agar kompon yang akan dicetak tidak melekat

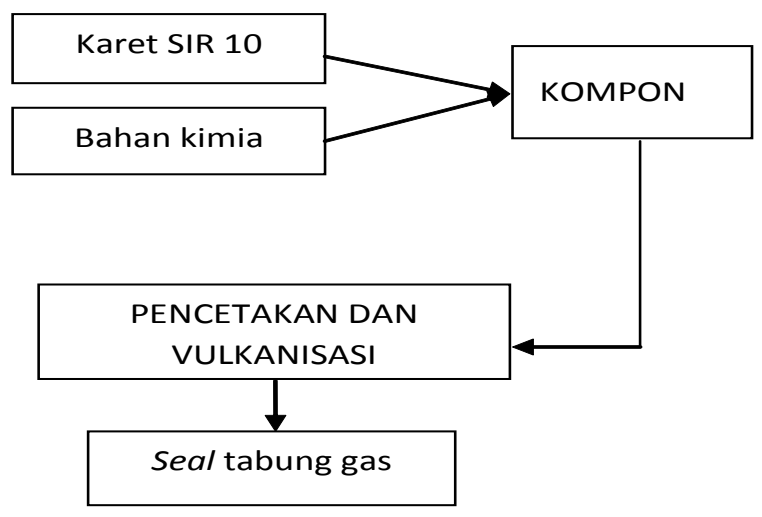

Gambar 1. Diagram pembuatan seal tabung gas.

pada cetakan. Kompon dimasukkan kedalam cetakan yang dipanaskan selanjutnya dipres pada suhu $150^{\circ} \mathrm{C}$, tekanan $150 \mathrm{~kg} / \mathrm{cm}^{2}$ selama 20 menit. Cetakan didinginkan dan produk seal tabung gas dilepas dari cetakan. Diagram pembuatan seal tabung gas ditampilkan pada Gambar 1.

\section{HASIL DAN PEMBAHASAN Syarat Mutu Seal Tabung Gas}

Syarat mutu seal tabung gas sesuai SNI 7655:2010 terdiri dari 9 parameter (BSN, 2010). Selengkapnya seperti pada Tabel 2.

Tabel 2. SNI 7655: 2010 (seal tabung gas LPG).

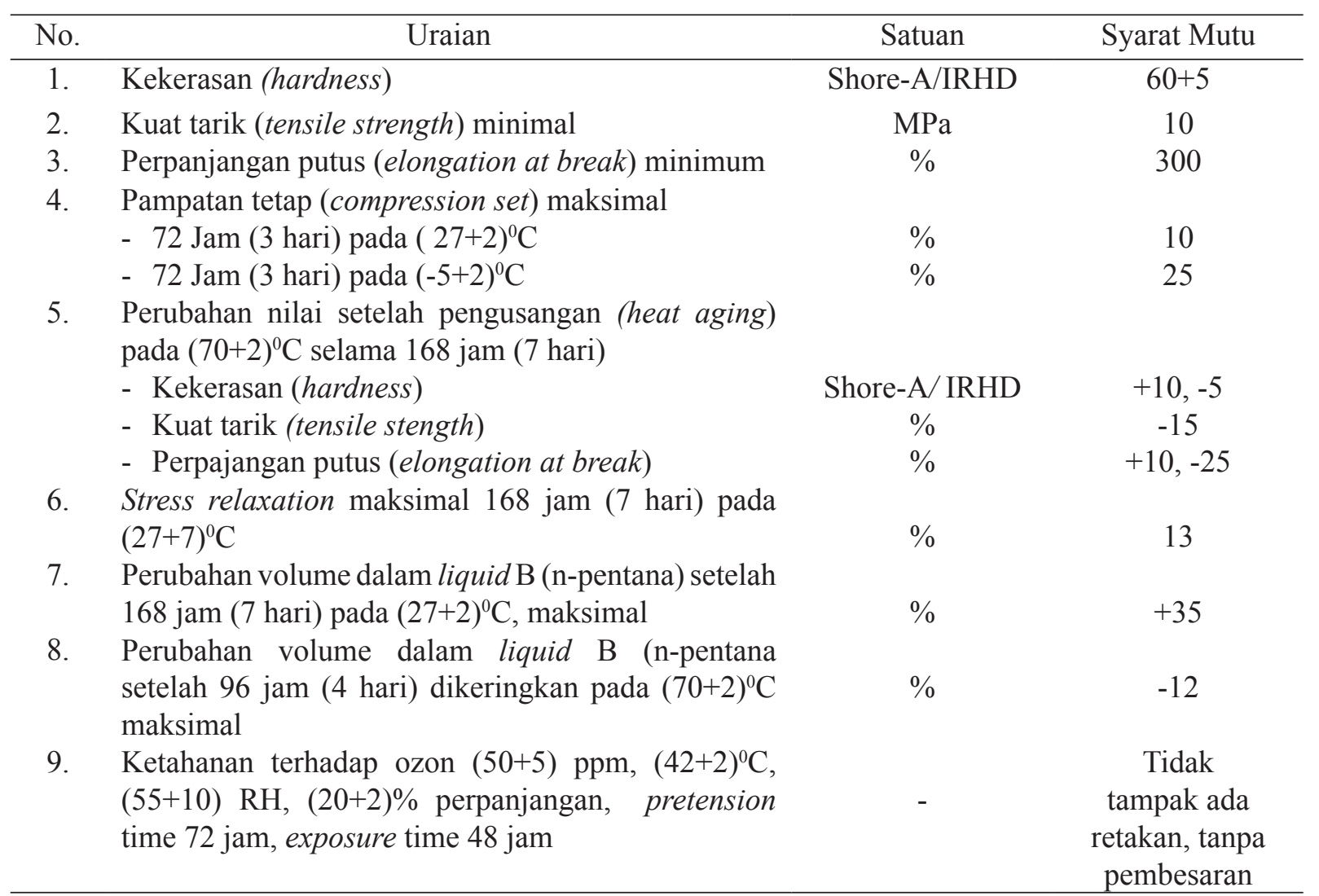




\section{Hasil Pengujian Seal Tabung Gas}

Hasil pengujian seal tabung gas yang dibuat dari karet alam dengan bahan pengisi pasir kuarsa sebagai pengganti karbon hitam yang meliputi visual, kekerasan, tegangan putus, perpanjangan putus, pampatan tetap, pengusangan, dan ketahanan terhadap ozon seperti pada Tabel. 3 .

\section{Visual}

Penilaian visual dilakukan untuk mengetahui apakah ada produk yang cacat. Cacat produk pada pembuatan seal tabung gas dapat disebabkan karena proses pencampuran bahan yang tidak merata, formula yang tidak tepat, temperatur yang tidak tepat, tekanan dan waktu pencetakan yang tidak tepat pada saat vulkanisasi. Kecerobohan pada saat pelepasan seal tabung gas dari cetakan juga dapat menyebabkan cacat produk (Cifriadi, 2016). Jika beberapa hal penyebab cacat produk tersebut dapat diantisipasi maka produk yang akan dihasilkan menjadi baik. Hasil pengujian visual seal tabung gas menunjukkan tidak ada cacat produk.

\section{Kekerasan}

Pengujian kekerasan (hardness) dilakukan untuk mengetahui kekerasan seal tabung gas yang dihasilkan. Kekerasan produk karet sangat dipengaruhi oleh jenis dan jumlah bahan pengisi yang digunakan. Hasil pengujian kekerasan ditampilkan pada Gambar 2. Hasil pengujian keke- rasan seal tabung gas tertinggi diperoleh pada formula (A) yaitu $60 \pm 5$ shore $A$, dan nilai terendah pada formula (E) yaitu $51 \pm 6$ shore A. Persyaratan kekerasan seal tabung gas menurut SNI adalah $60 \pm 5$ shore $\mathrm{A}$.

Penggunaan pasir kuarsa sebagai bahan pengisi dapat menurunkan nilai kekerasan. Menurut Prasetya \& Marlina (2013) penggunaan bahan pengisi dapat meningkatkan atau menurunkan kekerasan dari produk karet yang dihasilkan. Lebih lanjut Cifriadi (2016) menyatakan bahwa pembuatan produk barang jadi karet sangat dipengaruhi oleh penggunaan jenis dan jumlah bahan pengisi. Bahan pengisi terdiri dari dua macam yaitu bahan pengisi aktif dan bahan pengisi tidak aktif (Cifriadi, 2016). Pasir kuarsa yang mengandung silika merupakan bahan pengisi tidak aktif oleh karena itu penggunaannya akan menurunkan kekerasan produk.

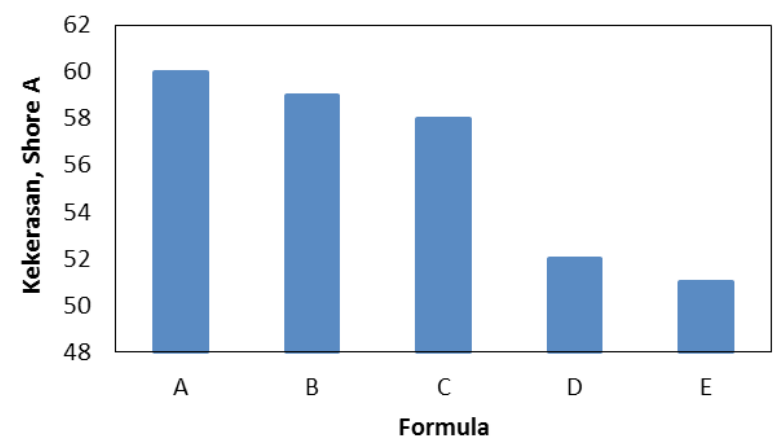

Gambar 2. Hasil pengujian kekerasan.

Tabel 3. Hasil pengujian sifat fisika seal tabung gas.

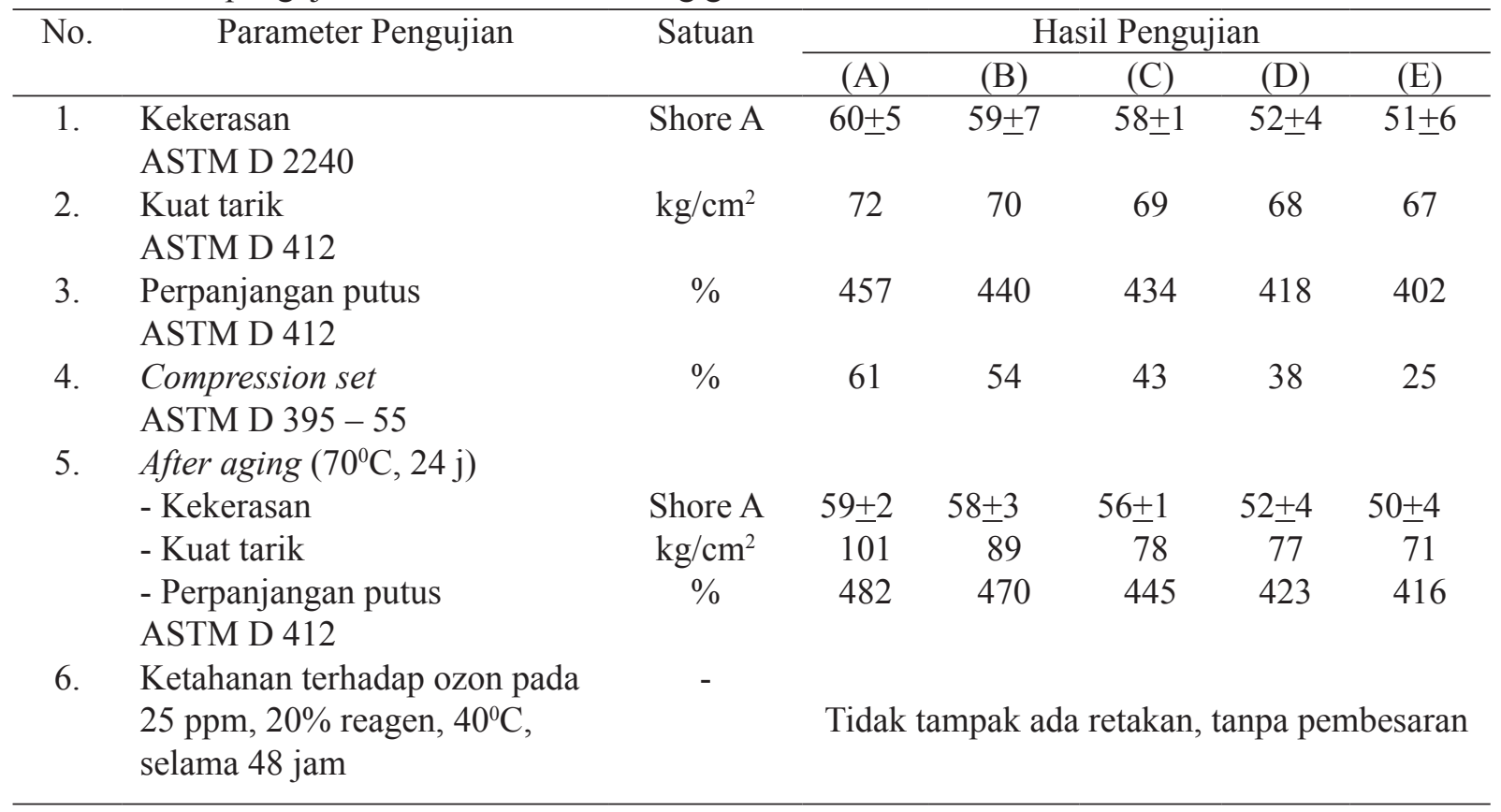




\section{Tegangan putus}

Tegangan putus (tensile strength) adalah besarnya beban yang diperlukan untuk merenggangkan potongan uji vulkanisat karet sampai putus dalam $\mathrm{kg}$ per $\mathrm{cm}^{2}$ luas penampang sebelum direnggangkan. Melalui pengujian ini dapat ditetapkan waktu vulkanisasi optimum dan pengaruh pengusangan. Gambar 3 menunjukkan hasil pengujian tegangan putus seal tabung gas dari berbagai formula penelitian.

Nilai tertinggi tegangan putus diperoleh pada formula (A) yaitu $72 \mathrm{~kg} / \mathrm{cm}^{2}$, dan nilai terendah pada formula (E) yaitu $67 \mathrm{~kg} / \mathrm{cm}^{2}$. Persyaratan menurut SNI adalah minimum $10 \mathrm{~kg} / \mathrm{cm}^{2}$. Penggunaan pasir kuarsa sebagai bahan pengisi dapat menurunkan nilai tegangan putus seal tabung gas. Arizal (1984) menyatakan bahwa salah satu sifat dasar elastomer adalah daya tegangan putusnya. Elastomer memiliki sifat elastisitas yang baik sehingga dapat dipergunakan sebagai bahan pada pembuatan produk-produk tertentu. Cifriadi (2016) menegaskan bahwa berbagai bahan yang ditambahkan akan mempengaruhi sifat tegangan putus barang jadi karet, salah satunya adalah bahan pengisi.

\section{Perpanjangan putus}

Perpanjangan putus (elongation at break) adalah pertambahan panjang potongan uji vulkanisat karet pada saat direnggangkan sampai putus yang dinyatakan dengan persen (\%) dari panjang potongan uji sebelum direnggangkan. Pengujian perpanjangan putus bertujuan untuk mengetahui sifat tegangan dan regangan vulkanisat karet dan sifat termoplastik, serta penentuan yield point melalui kekuatan dan pertambahan panjang vulkanisat karet ketika mengalami penarikan sampai perpanjangan tertentu dan sampai putus.

Gambar 4 menunjukan nilai tertinggi perpanjangan putus diperoleh pada formula (A) $457 \%$. Nilai terendah pada formula (E) yaitu $414 \%$. Penggunaan pasir kuarsa sebagai bahan pengisi dapat menurunkan nilai perpanjangan putus seal tabung gas. Sebagaimana halnya dengan sifat tegangan putus, maka sifat perpanjangan putus produk barang jadi karet seperti seal tabung gas akan dipengaruhi oleh penggunaan jenis dan jumlah bahan pengisi (Cifriadi, 2016; Haryadi, 2000).

\section{Pampatan tetap}

Pampatan tetap (compression set) adalah pengujian untuk mengetahui perubahan dimensi vulkanisat karet jika diberi tekanan pada waktu tertentu, dengan standar maksimum terjadi perubahan 30\%. Pada Gambar 5 dapat dilihat nilai tertinggi pampatan tetap dihasilkan pada formula (A) dengan nilai $61 \%$, dan nilai terendah pada formula (E) dengan nilai 25\%. Standar SNI adalah minimum 25\%. Penggunaan pasir kuarsa sebagai bahan pengisi dapat menurunkan nilai pampatan tetap seal tabung gas. Menurut Cifriadi (2016) penggunaan bahan-bahan tambahan seperti bahan pengisi pada pembuatan produk karet dapat meningkatkan atau menurunkan nilai pampatan tetap dari produk tersebut.

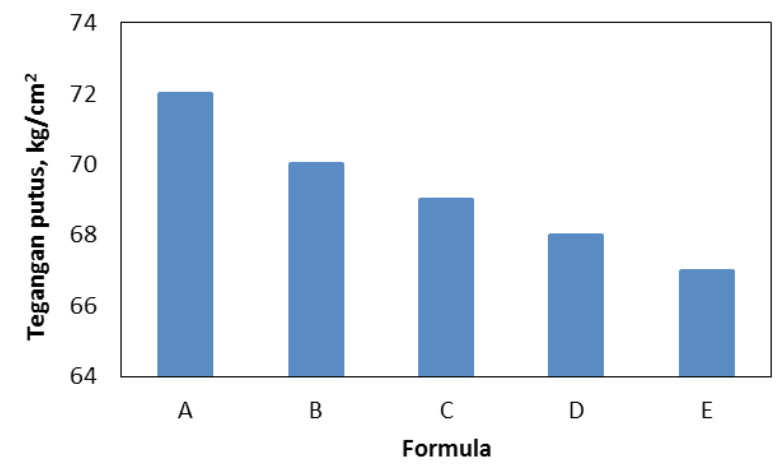

Gambar 3. Hasil pengujian tegangan putus.

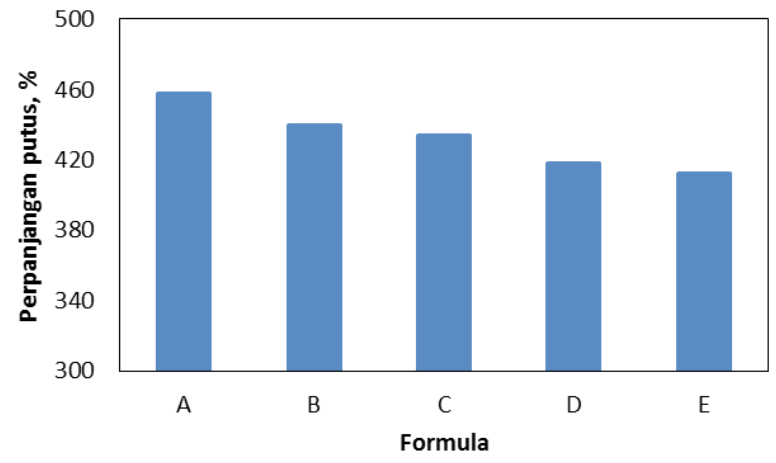

Gambar 4. Hasil pengujian perpanjangan putus.

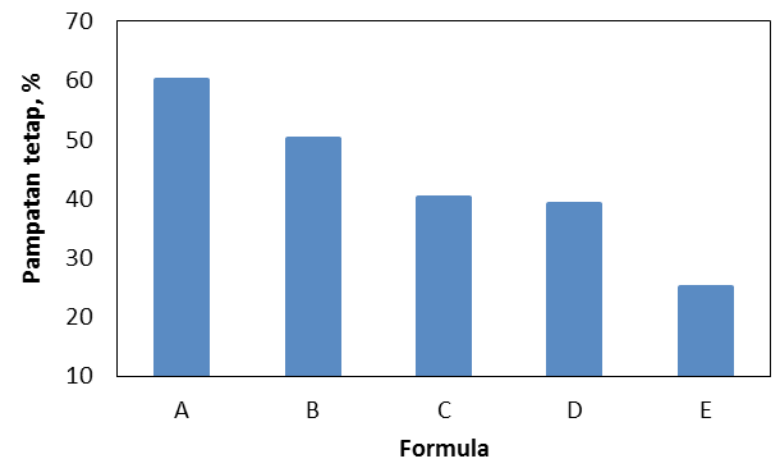

Gambar 5. Hasil pengujian pampatan tetap. 


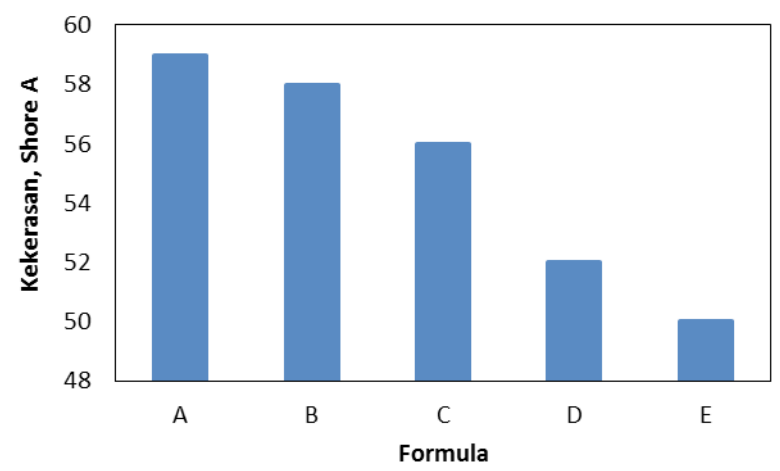

Gambar 6. Perubahan kekerasan setelah pengusangan.

\section{Pengusangan}

Pengusangan mengakibatkan menurunnya sifat fisika produk karet, seperti karet menjadi keras dan retak atau lunak dan lengket. Penurunan sifat fisika disebabkan terjadi degradasi karet oleh oksidasi oksigen dan ozon. Ketahanan pengusangan seal tabung gas menunjukkan ketahanan seal tabung gas terhadap oksidasi dalam masa penyimpanan. Pengusangan mengakibatkan penurunan nilai tegangan putus dan perpanjangan putus karena panas akan mempercepat proses oksidasi dan degradasi produk. Perubahan kekerasan (Shore A), tegangan putus $\left(\mathrm{kg} / \mathrm{cm}^{2}\right)$, dan perpanjangan putus (\%) setelah pengusangan dapat dilihat pada Gambar 6, 7, dan 8.

Selaras dengan hasil pengujian kekerasan, tegangan putus dan perpanjangan putus maka hasil pengujian terhadap pengusangan dari ketiga sifat tersebut menunjukkan penurunan. Setelah dilakukan pengusangan sifat kekerasan menurun seiring dengan penggunaan bahan pengisi pasir kuarsa, demikian juga tegangan putus dan perpanjangan putusnya. Hal ini sangat sesuai dengan pernyataan Cifriadi (2016) yang menyatakan bahwa penggunaan jenis dan jumlah bahan pengisi akan berpengaruh pada sifat kekerasan, tegangan putus dan perpanjangan putus serta pengusangannya.

\section{Ketahanan tehadap ozon}

Hasil pengujian ketahanan tehadap ozon, 25 ppm, $20 \%$ reagen, $40^{\circ} \mathrm{C}$, selama 48 jam pada seal tabung gas formula (A) sampai formula (E) tidak mengalami keretakan. Hal tersebut menunjukkan bahwa seal tabung gas yang dibuat dari bahan pengisi pasir kuarsa sebagai pengganti karbon hitam menghasilkan produk yang baik secara fisik. Arizal (1984) menyatakan bahwa penggunaan elastomer seperti karet alam untuk pembuatan

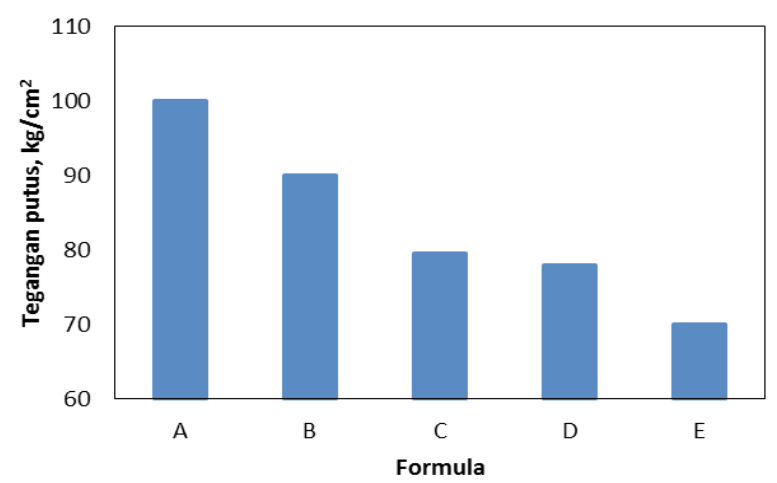

Gambar 7. Perubahan tegangan putus setelah pengusangan.

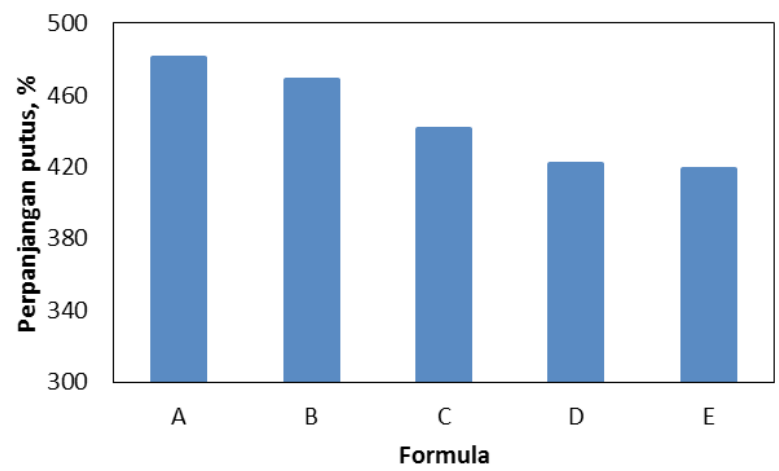

Gambar 8. Perubahan perpanjangan putus setelah pengusangan.

berbagai produk lebih baik karena memiliki ketahanan ozon yang baik.

\section{KESIMPULAN}

Pasir kuarsa merupakan bahan sumber daya alam lokal yang memiliki potensi untuk menjadi bahan pengisi pada pembuatan seal tabung gas. Pembuatan seal tabung gas berbahan karet alam dengan bahan pengisi pasir kuarsa pengganti karbon hitam dapat memenuhi sebagian persyaratan SNI. Penggunaan pasir kuarsa dapat menurunkan nilai kekerasan, tegangan putus, perpanjangan putus, pampatan tetap, dan pengusangannya.

\section{UCAPAN TERIMA KASIH}

Ucapan terima kasih dan penghargaan disampaikan kepada Kepala Baristand Industri Palembang yang telah memberikan dukungan, izin dan fasilitas untuk pelaksanaan penelitian. Penelitian ini terlaksana atas biaya dari Anggaran Dipa Baristand Industri Palembang tahun 2011. Ucapan terima kasih juga disampaikan kepada tim yang telah membantu kegiatan ini dan kepada semua pihak yang tidak dapat disebutkan satu per satu. 


\section{DAFTAR PUSTAKA}

Arizal. R., (1984). Pengetahuan dasar elastomer. Bogor, Indonesia: Balai Penelitian Teknologi Karet.

Bahri, S. (2015). Pemanfaatan batu apung dan clay pada pembuatan kompon karet bantalan kaki sepeda motor. Jurnal Tekmi, 2(1), 33-37.

Bondan, A. T. (2013). Nano brushing rubber sebagai bahan pengisi dalam pembuatan karet tromol kendaraan bermotor roda dua. Jurnal Dinamika Penelitian Industri, 24(2), 82-89.

BSN, (Badan Standardisasi Nasional). (2010). Standar Nasional Indonesia SNI 7655.2010: Karet perapat (rubber seal) pada katup tabung LPG. Jakarta, Indonesia: BSN.

Cifriadi,A.(2016).Pengetahuanbahanuntukpembuatan produk karet (Makalah Pelatihan). Palembang, Indonesia: Balai Riset dan Standardisasi Industri Palembang.

Cifriadi, A., \& Maspanger, D. (2005). Sifat teknis vulkanisat sol sepatu karet alam menggunakan bahan pengisi abu terbang. Bogor, Indonesia: Balai Penelitian Teknologi Karet.

Daud, D. (2015). Kaolin sebagai bahan pengisi pada pembuatan kompon karet: Pengaruh ukuran dan jumlah terhadap sifat mekanik fisik. Jurnal Dinamika Penelitian Industri, 26(1), 41-48.

Fachry, A. R., Sari, T. I., Putra, B. A., \& Kristianto, D. A. (2012). Pengaruh penambahan filler kaolin terhadap elastisitas dan kekerasan produk souvenir dari karet alam (Hevea brasiliensis). Dalam Seminar Nasional Teknologi Oleo dan Petrokimia Indonesia (TOPI). Pekanbaru: Jurusan Teknik Kimia Universitas Riau.

Fachry, A. R., Sari, T. I., Sthevanie, S., \& Susanti, S. (2014). Pengaruh filler campuran silika dan kulit kerang darah terhadap sifat mekanis kompon sol sepatu dari karet alam. Jurnal Teknik Kimia, 20(3), 1-11.

Haryadi, B. (2000). Pengaruh bahan pengisi terhadap sifat kompon barang jadi karet untuk sol sepatu menggunakan carbon black. Palembang, Indonesia: Balai Litbang Industri Palembang.
Marlina, P., Pratama, F., Hamzah, B., \& Pambayun, R. (2015). Karakteristik kompon karet dengan bahan pengisi arang aktif tempurung kelapa dan nano silika sekam padi. Jurnal Teknologi Industri Pertanian, 25(1), 85-93.

Marlina, P., \& Rahmaniar. (2012). Penggunaan bahan pengisi nano komposit silika karbida pada pembuatan kompon ban dalam kendaraan bermotor roda dua. Jurnal Dinamika Penelitian Industri, 23(2), 91-98.

Nasution, D. Y. (2006). Pengaruh ukuran partikel dan berat abu sekam padi sebagai bahan pengisi terhadap sifat kuat sobek, kekerasan dan ketahanan abrasi kompon. Jurnal Sains Kimia, 10, 86-91.

Nella, F., Fachry, A. R., \& Suharman, S. (2016). Mempelajari sifat fisika sol karet cetak dengan filler cangkang telur ayam. Jurnal Dinamika Penelitian Industri, 27(1), 69-75.

Nuyah, N. (2012). Penggunaan arang cangkang sawit sebagai bahan pengisi dalam pembuatan kompon selang karet. Jurnal Dinamika Penelitian Industri, 23(1), 51-56.

Prasetya, H. A. (2012). Arang aktif serbuk gergaji sebagai bahan pengisi untuk pembuatan kompon ban luar kendaraan bermotor. Jurnal Riset Industri, $7(2), 165-173$.

Prasetya, H. A., \& Marlina, P. (2013). Penggunaan sekam padi sebagai bahan pengisi dan antioksidan pada pembuatan kompon karet. Jurnal Dinamika Penelitian Industri, 24(2), 66-73.

Sasongko, A. R. (2012). Studi pengaruh ukuran partikel dan jumlah phr carbon black sebagai bahan pengisi terhadap sifat mekanik produk karet alam (Skripsi). Universitas Indonesia.

Sodik, S. (1995). Inventarisasi endapan lempung dan pasir kuarsa di daerah limapuluh koto (Laporan). Kabupaten Limapuluh Koto, Indonesia: Dinas ESDM.

Vachlepi, A., \& Suwardin, D. (2015). Kajian pembuatan kompon karet alam dari bahan pengisi abu briket batubara dan arang cangkang sawit. Jurnal Dinamika Penelitian Industri, 26(1), 1-9. 
